\title{
THE ROLE OF INNOVATION IN SUSTAINABLE REGIONAL DEVELOPMENT: CASE OF LATVIA
}

Dace ŠTEFENBERGA, Entrepreneurship, Innovation and Regional Development Centre, Faculty of Economics and Management; Ventspils University of Applied Sciences, Inženieru street 101, Ventspils, LATVIA; daces@ venta.lv (corresponding author) Biruta SLOKA, Faculty of Business, Management and Economics, University of Latvia, Aspazijas bulv. 5, Riga, LATVIA; biruta.sloka@lu.lv

\begin{abstract}
Innovation - it is a term that we use for decades, but true meaning of this term changes also for decades, according to dynamic environment we are living in. There is now beginning of the $4^{\text {th }}$ industrial revolution and what has been said in World Economic forum, issues are not about technologies anymore, they are about society. Innovation and entrepreneurship in regions is one of essential tools, in added value creation in economics and in development in national level. It is very important to encourage creativity, new ways of thinking and continuous process of learning of individuals. Aim of the current paper is to investigate development of application of innovations evaluated internationally for the country by GCI and reflect the entrepreneur's opinions for innovation applications aspects. Research methods applied: scientific publications and previous conducted research results analysis, analysis of development of reflection innovation aspect in GCI, analysis of strategic planning documents and guidelines of EU and Latvia and survey of inhabitants of local community survey of entrepreneurs of Kurzeme region in Latvia on their opinion about participation in the processes to make changes in development of region and local community. There are some different approaches how to measure competitiveness of state economy and competitiveness in regional level. Statistical data shows situation from point of view in national level, Regional level and local community level have to be researched detailed, and every situation, which can make impact on level above, have to be taken into account. . Main results were related with issue, that tenants of region at very low level evaluate impact of state as institution and management system in national level, better evaluation of local government institutions, but at the same time there is lack of desire to participate actively in processes of local community to encourage changes in regional level.
\end{abstract}

Keywords: Global Competitiveness Index, innovation, regional development.

\section{INTRODUCTION}

The latest stage of development in the innovation theory and practice evolved in the first decades of the $21^{\text {st }}$ century, when relentless work on pre-established models and schemes, nevertheless did not shed enough light on why some companies with their new ideas were able to become more successful and develop, while others with equally successful ideas have not been able to achieve a competitive level of development.

Latvia is monocentric state, because more than half of inhabitants are living and working in the capital city of Latvia - Riga, and Riga region has $135 \%$ of average level of GDP of Latvia. There are Guidelines for regional development in 2021-2027 in development process today in Latvia, and one of the important issues is how to improve regional development in all regions of Latvia, not only in one region.

Previous tools and methods are not giving desired results, and it is important to seek for new solutions and tools. Examination of some state strategic planning documents, e.g. Science, Technology development and innovation guidelines 2014-2020 showed, that goal of expenditures on research and development 1,5\% of GDP, will never be reached on the year 2020. It is necessary to find solutions how to grow incomes more than just automatically cut expenditures and costs. And this is the way when innovation in different ways - product, process, system, changes - comes on the stage. Indicated object: inovation process in sustainable regional development through encouragement of local community.

Research aim: to investigate development of application of innovations evaluated internationally for the country by GCI and reflect the entrepreneur's opinions for innovation applications aspects. Innovation as a definition of changes in a systemic aspect and relations between innovative entrepreneurship and sustainable development and competitiveness of regions. Human resources as a main tool for innovation creation and readiness to participate in solving these tasks in regional environment

Research methods: Methods, used in this research includes analysis of scientific publications and previous conducted research results analysis, analysis of related statistical data and analysis of survey of entrepreneurs of Kurzeme region in Latvia.

\section{Definitions of Innovations in Sustainable Development of Regions}


Studies of latest researches show that innovation concept and its definition and classification depends on implementation - more important role in innovation definition gains systemic and multidimensional approach (Andersson, Karlsson, 2004; Godin 2015), researchers focus on cross-industry innovation capability and its systematism (Dosi, Grazzi, Moschella, 2017; Taalbi, 2017). Central Bureau of Statistics of Latvia defines innovation as "implementation in practice of a new or fundamentally improved product (goods or services) or a new market method or organizational method"'(Central Bureau of Statistics, 2018).

Global scientific environment stressed discussions of innovational role in entrepreneurship and economic development to diversify approbated classification of innovation for creation of new, competitive solutions. Leadership style, focused on the direction definition and its execution control, is not long-term solution anymore. For identification of goals and objectives important meaning should be addressed to the secondary factors - methods and tools of reaching goals and goals and priorities at themselves have been changed in so dynamic economic environment. (Sharmer, 2018)

Investigations of regional development, made by researchers (Anderson, Karlsson, 2004) who specialized in regional innovation systems, shows that innovative business have tendencies to be spatially localized while standard business has tendency to become globalized. For best results all three participants in innovation systems (Fini, Grimaldi, Santoni, Sobrero 2011) (academic environment, researchers; business supporting institutions as business incubators and science parks and entrepreneurs) should cooperate very close (Shepard, 2017). Scientists devoted last decades for seeking most effective cooperation models and approbation of them. At early beginning it was Triple Helix (Etzkowitz, 2001; Leidesdorff, 2011), continuing on Quadruple Helix (Arnkil, et al. 2010) and actual today is Penta Helix (Ostrom, 2010; Calzada, 2017). Most important part of Penta Helix is social entrepreneurship and involvement of society. This approach is about to reconfigure the role of education and universities and demands new way of thinking and knowledge creation and acquiring in the business education, to emphasize approach "learning by doing" (Partanen, 2017). Company carries out when it develops its innovative idea in the market. These include the formation of interest groups, or clustering, networking, openness of ideas, education (higher, technological), creativity, knowledge formation. At this level of cooperation, among the most important tasks are development of creativity and knowledge-building. According to large company owner and entrepreneur for decades Uldis Pîlēns, innovative also could be - using non-traditional methods in usual environment in the right time. He also stresses that in moments of crisis usually entrepreneurs start to become innovators: "Troubles and problems are mothers of innovations" (Pīlēns, 2019). Uldis Pīlēns suggestions are important to consider as he is one of the most successful entrepreneurs in Latvia.

\section{Levels of innovations and competitiveness}

Sustainability and competitiveness are present in all levels of global environment. We can also define what specific aspect of innovation include each level.

\begin{tabular}{|l|}
\hline \multicolumn{1}{|c|}{ MICRO } \\
Level of enterprises \\
- ability to propose \\
products and \\
services more \\
effective than \\
competitors \\
\hline
\end{tabular}

\begin{tabular}{|l|}
\hline \multicolumn{1}{|c|}{ MESO } \\
Level of economic \\
activities of \\
sectors, clusters or \\
regions
\end{tabular}
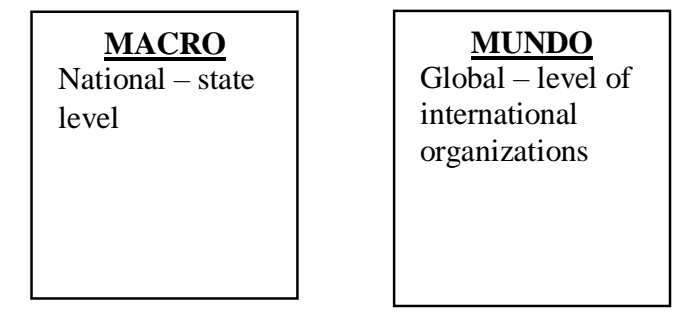

Source: Dace Štefenberga construction based on Porter, 1990; Sharmer, 2018

Figure 1. Levels of competitiveness

According to Shapiro, 2002, strategic competitiveness ensured in entrepreneurship has following conditions: strategic, focus on value creation, underlines leadership, prefer crucial role of people - innovation is created by people for people.

Starting with competitiveness in global level, it is necessary to understand that there are different global institutions, e.g. World Economic Forum, International Currency foundation, World Bank and other institution, which leaves impact on every level below.

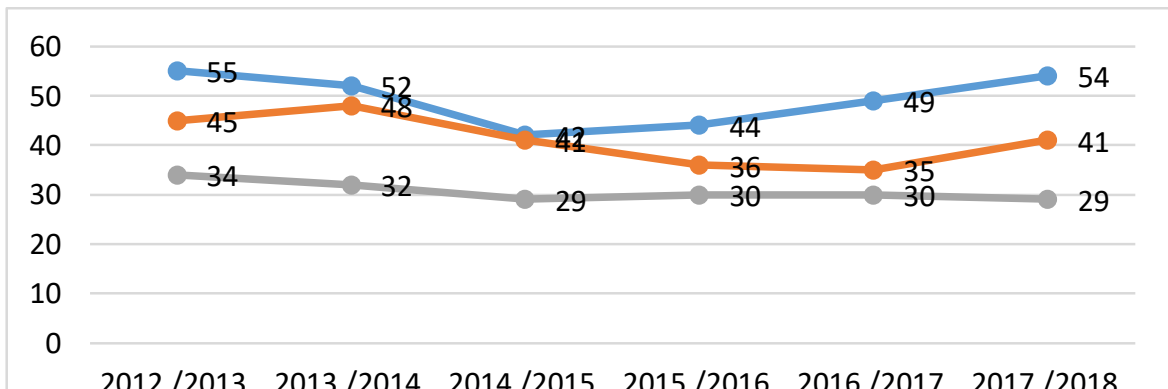

2012./2013. 2013./2014. 2014./2015. 2015./2016. 2016./2017. 2017./2018.

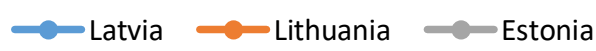

Dace Štefenberga construction based on, Sources: GCI 2012, GCI 2013, GCI 2014, GCI 2015, GCI 2016, GCI 2017

Figure 2. Global Competitiveness Index of Baltic States 2012-2018 
As has been stated in the table above, in Global Competitiveness index during last five years, Latvia in competitiveness fall behind both other Baltic States. Unfortunately, one of reasons of this is pillar 'innovation' which ensures average level of total index between 144 states of the world.

Another global measurement -The European Innovation Scoreboard (EIS, 2018) provides an assessment of the innovation performance of EU Member States and some third countries, as well as the strengths and weaknesses of national innovation systems, and evaluates their structure. The European Innovation Scoreboard of 2018 confirms that innovation performance in general both within the EU and for EU on a global scale is increasing, but the progress within the EU is uneven. The 2018 report demonstrates that innovations and business investment in Latvia are the weakest dimensions, while the strongest are the innovation-friendly environment and the financial and support system. In terms of human resource potential, Latvia is relatively close to the EU average in this field, ahead of moderate innovators, e.g. Spain, Italy, and Portugal. Latvia possesses comparatively good intellectual property readings in comparison with other countries. Moreover, in terms of number of people with higher education percentage-wise of the whole population, Latvia was expected to reach $34.0 \%$ in 2020 . This level already has been reached - from $40.7 \%$ in 2013 to $45.6 \%$ in 2017 - and it is one of the indicators contributing to Latvia joining the moderate innovators' circle.

Unfortunately, mostly used data for innovation evaluation - gross domestic expenditures on research and development shows a stagnation and decrease from year 1996 (0.397\%) to 2018 (0.44\%) in Latvia. Science, technology and innovation guidelines for 2014-2020 defined target to reach in 2020 - 1.5\% of GDP for research and development. Average European Community level is $2.07 \%$ in year 2019. These figures and differences between them shows problematic issues in public financing of research and development in state as well as thing that, possibly, something is not working in definition of tasks and strategies in state level. These are processes, describing innovation and competitiveness in national level.

There is highest level of regional differences in Latvia among the European countries - Riga (capital) region has $135 \%$ of GDP in year 2016 from average national level of GDP. Kurzeme region - 75\%, Vidzeme region - 66\%, Zemgale region - 63\%, and Latgale region 51\% (Project of guidelines for regional politics 2021-2027, 2019)

One of challenges identified is development and implementation of industry politics, because this process is organized in not coordinated way and isolated from priorities of territory development. Guidelines of regional politics are developed for years, based not on requirements of local communities, but on industry necessities. There are decrease of inhabitants from year 2010 to 2019 for 200 thousand in Latvia. In the beginning of 2019 total populations of Latvia was 1 million 920 thousand. Rate of decrease in year 2018 is $0.7 \%$ (in year 2010, - 2,2\%). Density of population is only 30 people per 1 sq.km $(C S P, 2019)$ which is quite small in comparison with other countries.

\section{Research results of Kurzeme region}

Competition for research projects have lead to results that in the state programmes in Latvia 'EKOSOC_LV" and "INTERFRAME-LV" could participate also Ventspils University of Applied Sciences, University of Latvia and other universities and public institutions could participate in this state research programme in order to define scenarios of inclusive regional development. Authors of this publication participated in projects in this research programme, and there was research made during this project. Questionnaire of the project included 3 blocks of questions, related to evaluation of 1) state as institution, 2) local government institutions, 3) local communities - readiness for involvement of inhabitants of local government processes

Results showed that local government organizations are able to create networks of entrepreneurship with local enterprises in order to solve challenges of involved parties. Results showed that also there are very low wish of tenants to acquire new knowledge, skills and participate in study programs, study courses in Kurzeme region. Tenants feel wish to cooperate with local government institutions and local communities in order to increase their economic activities..

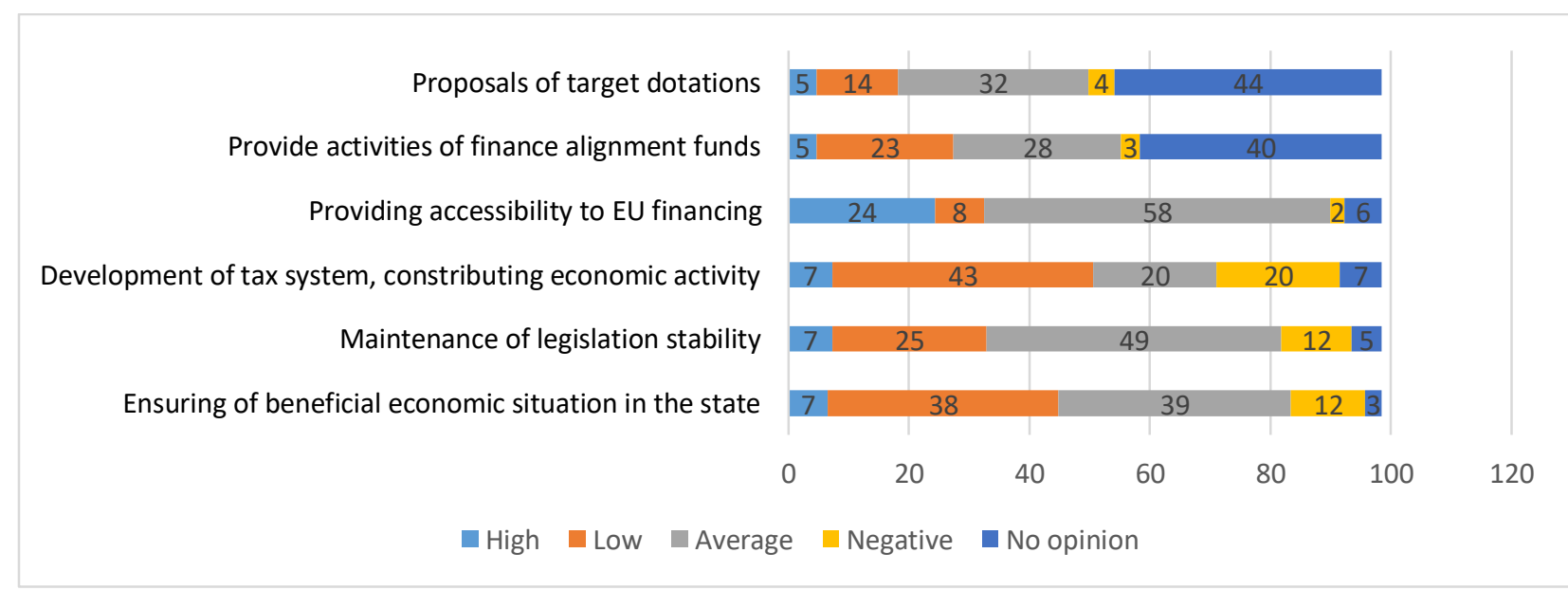

Source: Dace Štefenberga construction based on survey data

Figure 3. Evaluation of state as institution by entrepreneurs, \%, 2016 
Research results showed that inhabitants (tenants) see most visible impact of state as institution in the providing accessibility of EU financing as well very essential for tenants, including entrepreneurs is stability of legislation otherwise if legislation changes very frequently, people are not able to handle with these changes. Evaluations of tenants for implemented national politics for encouraging promotional economic activity tax system is very low and negative. Questions about proposals of target dotations and activities of finance alignment funds are not quite relevant for respondents, and respondents have no strong opinion about it, while they, possibly, are not well informed about these questions. According to results, high evaluation of impact of state as institution not exceed $7 \%$, that might show tendency how tenants evaluate state institutions.

Next block of questions included evaluation of local governmental institutions in Kurzeme region. Most of respondents were inhabitants of Kurzeme region, therefore it was very important for them. There were many residents of Ventspils city, and, possible, that results could be different, if most of respondents could be from only rural areas. Nevertheless, most of respondents work in Ventspils city, but live in rural areas of Kurzeme region: Pope, Ugāle, Piltene, Ance, even Kuldīga, Talsi and territories around them. Local government is institutional level, but smaller and closer to the inhabitants of region, and therefore feedback from institutional activities is more relevant than in state level.

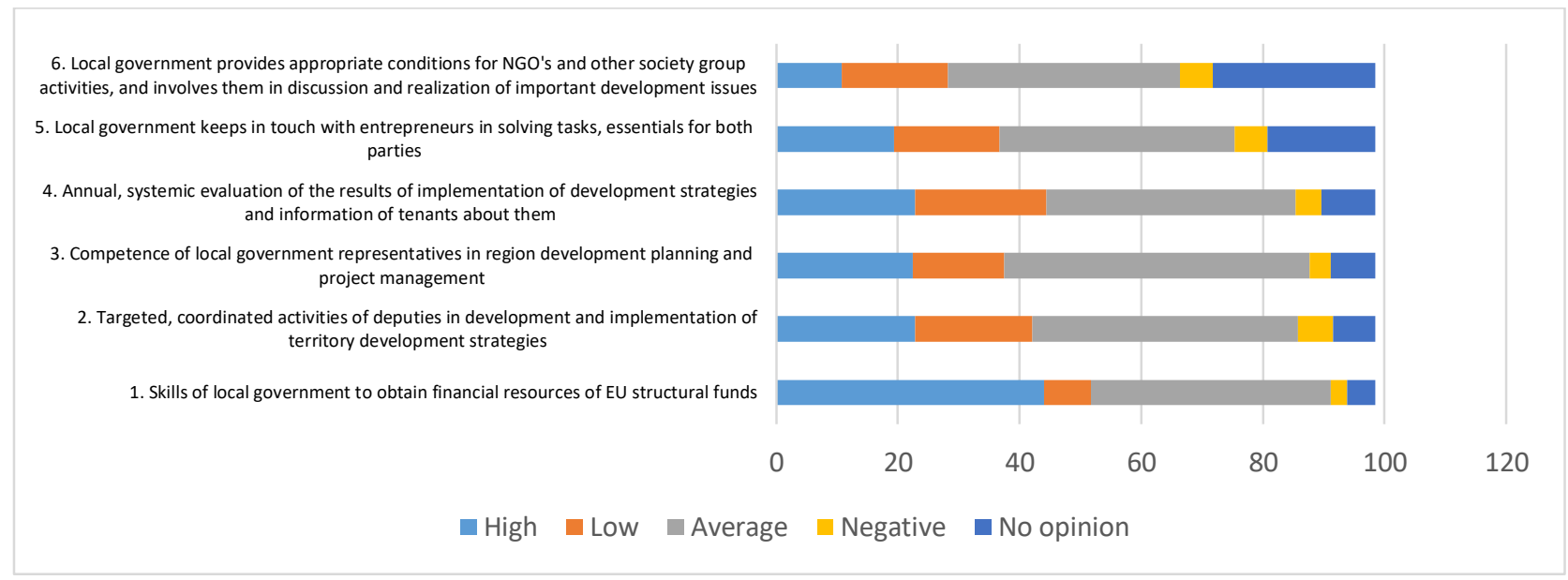

Source: Dace Štefenberga construction based on survey data

Figure 4. Evaluation of local government institution by entrepreneurs, 2016

Tenants of region at the highest level evaluated skills of local governmental institutions to attract financing of EU funds, use of them and competence of employees of local government institutions in planning process and project management. Next good evaluation is for targeted, coordinated activities of deputies in development and implementation of strategies for local community. Most answer "no opinion" is on questions about conditions, what local government provides for NGO's and other society group activities and involvement of them in discussions and realization of important development issues. One of the reason could be, that insufficient information do NGO's are involved in processes related to the important issues for these groups and even decision making process. This block of questions also have no very negative results, lowest results related with topics, how residents are informed about region development programmes and implementation and evaluation results of them. Increasing of involvement of inhabitants is possible to increase results of common work and improve opinion of inhabitants about their collaboration and involvement in processes. Next block of questions touched local communities in local government territories.

6. Visible readiness to accept changes in work, society, external environment

5. Tenants of region cooperating not only in activities, related to sports and culture, but in creation of economic cooperation projects

4. Readiness of tenants to get new knowledge, in participation of lectures, seminars and life-long studies

3. Activities of tenant groups for acquisition and dissemination of innovative ideas

2. Readiness of local tenants for economic activities in order to rise self incomes

1. Wish of local tenants to participate in solving tasks of local government in active cooperation together

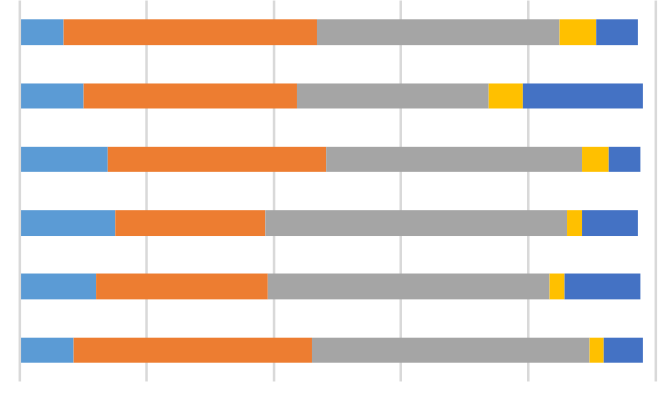

$$
\begin{aligned}
& \begin{array}{llllll}
0 & 20 & 40 & 60 & 80 & 100
\end{array} \\
& \text { High Low Average Negative No opinion }
\end{aligned}
$$


Tendencies, we can see in the table of results, show that evaluation of state is very low, nevertheless in the same time, residents evaluate very low the readiness of local community, (in the same time - readiness of themselves) to participate in practical decision making process and take actions in increase of wellbeing of local community, also receive changes in the work, society, local environment. External environment is changing rapidly and everyone has to take correct and right decisions in this dynamic environment, readiness to take changes should be at high level. According to the thesis of Otto Sharmer (Sharmer, 2018) we have to make decisions already today, based on perspectives of tomorrow, and only those enterprises, which use innovative approaches, guided by source of future, than repeating use of past models, will be successful and able to give more goodness for society. These are things that we can see in today's society. "That is due to me...", "State is obliged to provide me with...", "Why state is doing nothing?..." etc. statements. I am sure that "state" is people, creating this "state". More than $40 \%$ evaluated very low readiness of local community (including themselves as a citizens) to take actions in economic activities and even in increasing self incomes. This result testifies about not engagement in processes in the local community. Problem even in some how is more deeper, because of burnout of employees, disinclination to work in industry, not a wish to "flush-up" about own idea, are relevant to the results of enterprises and also public institutions in general. Performance of individual level reflects in results and performance of institutional level.

\section{CONCLUSION AND DISCUSSION}

1. Entrepreneur generates social and economic benefits, focus on innovation and transformation starts at individual level, therefore important is social capital and enterprises forms near to living space

2. Traditional (non - innovative) and innovative entrepreneurship has different competitiveness and sustainability factors, performance of them affected by dynamic external environment and specialization of regions. It is necessary to respect resources of region, including natural resources and specialization of corresponding region in regional development strategies.

3. It would be necessary to strengthen cooperation at the regional level, as mentioned above, by strengthening cooperation between higher education and research, local communities and municipalities and entrepreneurs.

4. Regional public institution (local communities, NGOs), the most important tasks are to provide research and development activities, and boost creativity, networking, social capital development. There are also regional universities, universities of applied sciences, knowledge centers at this level, and it also sees active collaboration in the development of technology parks and business incubators.

5. The interrelation higher education institutions with the individual level of entrepreneurs is strong - mutual cooperation in the promotion of entrepreneurship takes place - local communities and knowledge centres are an essential human capital development platform that actively participate on individual level.

6. Modifying of systemic innovation in regional level defines smart specialization confirms thesis that cooperation model depends from region knowledge centres and regional specialization.

7. Smart specialization in context of innovative entrepreneurship require use of local resources with innovative approach to minimize consumption of resources and impact on environment.

Acknowledgement. The research was supported by the National Research Programme "Latvian Heritage and Future Challenges for the Sustainability of the State" project "Challenges for the Latvian State and Society and the Solutions in International Context (INTERFRAME-LV)"

\section{REFERENCES}

1. Andersson M., Karlsson C. 2004. Regional Innovation Systems in Small \& Medium Sized regions A critical Review \& Assessment. - Working Paper Series in Economics and Institutions of Innovation 10, Royal Institute of Technology. Available at http:// www.infra.kth.se/cesis/document/WP10.pdf p.1-22 (accessed 12/09/2019)

2. Arnkil R., Jarvensivu A., Koski P., Piirainen T. 2010. Exploring Quadruple Helix.Outlining User Oriented Innovation Mode. Tampere, pp.131.

3. .Calzada I., Cowie P. 2017. Beyond Smart and Data-Driven City-Regions? Rethinking Stakeholder- Helixes Strategies. Regions Magazine, Vol 3084, pp. 23-28. https://doi.org/10.1080/13673882.2017.11958675

4. .Central StatisticalBureau - Centrālā Statistikas pārvalde, 2018. Definitions - Definīcijas, Available at https://www.csb.gov.lv/lv/statistika/statistikas-temas/ekonomika (accessed 01/08/2019).

5. Dosi G., Grazzi M., Moschella D. 2017. What do firms know? What do they produce? A new look at the relationship between patenting profiles and patterns of product diversification. Small Business Economics, Vol. 48(2), pp. 413-429. https://doi.org/10.1007/s11187-016-9783-0

6. .Etzkowitz H. 2011. The Triple Helix: university - industry - government innovation in action, Science Policy Institute, Sweden, p. 1-164.

7. .European Innovation Scoreboard, 2018, Available at ec.europa.eu/enterprise/policies/innovation/files/ius_2017_en.pdf. (accessed 18/02/2019.

8. Fini R., Grimaldi R., Santoni S., Sobrero M. 2011. Complements or substitutes? The role of Universities and Local context in supporting the creation of academic spin-offs. Research Policy, Vol. 40(8), pp. $1113-1127$. https://doi.org/10.1016/j.respol.2011.05.013 
9. Godin, B. 2015. Innovation Contested the Idea of Innovation Over the Centuries. London: Routledge, 354 p. https://doi.org/10.4324/9781315855608

10. Leidesdorff L.2011. The Tripple Helix, Quadruple Helix, ..., and an N-Tuple of Helices: Explanatory Models for Analyzing the Knowledge Based Economy. Journal of Knowledge Based Economy, Vol. 3(1), pp. 25-35 https://doi.org/10.1007/s13132-011$\underline{0049-4}$

11. Ostrom, E. 2010. Beyond Markets and States: Polycentric Governance of Complex Economic Systems. American Economic Review, Vol. 100(3), pp. 641-672. https://doi.org/10.1257/aer.100.3.641

12. Partanen J. 2017. The Team Coach's Best Tool. Tiimiakatemia, Finland, 128 p.

13. .Pīlēns U. 2019. (Mans) uzņēmēja kods (My Entrepreneur Code - in Latvian), Zvaigzne ABC, Rīga, 431 p.

14. Porter M.E. 1990. The Competitve Advantage of Nations, New York, Free Press, 875 p. https://doi.org/10.1007/978-1-349$\underline{11336-1}$

15. Ministry of Environment and Regional Development (VARAM), 2019. Project of Guidelines for Regional Politics of Latvia 2021-2027.

16. Šarmers, K.O. 2018. U teorija. Vadība no topošās nākotnes. Rīga: Zvaigzne ABC 447 lpp.

17. Schwab, K. 2012. Global Competitiveness Report 2012-2013., World Economic Forum, Available at www.weforum.org (accessed 12/07/2019)

18. Schwab, K. 2013. Global Competitiveness Report 2013-2014., World Economic Forum, www.weforum.org

19. Schwab, K. 2014.Global Competitiveness Report 2014-2015., World Economic Forum, www.weforum.org

20. Schwab, K. 2015. Global Competitiveness Report 2015-2016., World Economic Forum, www.weforum.org

21. Schwab, K. 2016. Global Competitiveness Report 2016-2017, World Economic Forum, Available at http://www3.weforum.org/docs/GCR2016-2017/05FullReport/TheGlobalCompetitivenessReport2016-2017_FINAL.pdf (accessed 09/06/2019)

22. Shapiro M.S. 2002. 24/7 Innovation. A Blueprint for Surviving and Thriving in a Age of Change. New York: McGraw Hill, 291 p.

23. Shepard J.M. 2017. When incubators evolve: New models to assist innovative entrepreneurs. International Journal of Entrepreneurship and Innovation Management, Vol. 21(1/2), pp. 86-104. https://doi.org/10.1504/IJEIM.2017.10002344

24. Taalbi J. 2017. What drives innovation? Evidence from economic history. Research Policy, Vol. 46(8), pp. $1437-1453$. https://doi.org/10.1016/j.respol.2017.06.007 